https:/ / doi.org/10.15407/mineraljournal.41.03.048

УДК $552+49.33$

\title{
С.Г. Кривдік
}

Інститут геохімії, мінералогії та рудоутворення

ім. М.П. Семененка НАН України

03142, м. Київ-142, Україна, пр. Акад. Палладіна, 34

E-mail:kryvdik@ukr.net

\section{СПЕЦИФІКА ПАРАГЕНЕЗИСІВ МІНЕРАЛІВ У КАРБОНАТИТАХ ЧЕРНІГІВСЬКОГО МАСИВУ (ЗАХІДНЕ ПРИАЗОВ'Я)}

\begin{abstract}
Карбонатити чернігівського карбонатитового комплексу контрастно відрізняються від подібних карбонатитів інших комплексів низкою мінералогічних, петрологічних та геохімічних особливостей. Найбільше вражає надзвичайно висока залізистість олівінів (у карбонатитах до $\mathrm{Fa}_{65}$, в ійоліт-мельтейгітах $-\mathrm{Fa}_{70}$ ). У карбонатитах і лужних породах виявлено широкі інтервали варіацій хімізму олівіну - від $\mathrm{Fa}_{10-15}$ до $\mathrm{Fa}_{70}$. При цьому проявляється залежність між залізистістю олівіну (та інших фемічних мінералів) і окисненістю заліза (кристалізацією магнетиту). Зі збільшенням кількості останнього підвищується магнезіальність олівіну. Залізисті олівіни асоціюють зі збагаченим залізом кальцитом $(1,4 \% \mathrm{FeO})$ та доломітом $(>5,8 \% \mathrm{FeO})$. Одним із факторів такої залежності вважаємо термічну дисоціацію сидеритової молекули $\left(\mathrm{FeCO}_{3}\right)$ карбонатитового розплаву з утворенням $\mathrm{Fe}_{3} \mathrm{O}_{4}$ (магнетиту), $\mathrm{CO}, \mathrm{CO}_{2}$ i C (графіту). Через відсадку магнетиту розплав збагачується $\mathrm{MgO}$, тому кристалізуються більш магнезіальні олівіни та інші мінерали. Це підтверджують також результати ізотопно-геохімічних досліджень: у кальцитах із залізистим парагенезисом $\delta^{18} \mathrm{O}$ i $\delta^{13} \mathrm{C}$ мають типово "карбонатитові" значення $(+6,1 \mathrm{i}-5,1 \%$ відповідно), а в магнезіальних (з магнетитом) проявлені відхилення від "глибинних" значень ( $\delta^{18} \mathrm{O}$ стає від +8 і до $+17,5 \%$, а $\delta^{13} \mathrm{C}--9,5 \%$ ). За ізотопними даними, температура у високозалізистому парагенезисі становить $1050{ }^{\circ} \mathrm{C}$, а у магнезіальному $-971^{\circ} \mathrm{C}$. Такі особливості карбонатитів чернігівського комплексу зумовлені абісальними умовами їх формування. Цей комплекс є одним із найбільш еродованих (до 20 км).
\end{abstract}

Ключові слова: карбонатити з високозалізистим олівіном (до $\mathrm{Fa}_{65}$ ), глибокий ерозійний зріз, дисоціація молекули $\mathrm{FeCO}_{3}$.

Вступ. Відомо, що в ізоморфних серіях мінералів (твердих розчинів) форстерит - фаяліт (проміжні хризоліт - гортоноліт), геденбергіт - діопсид (проміжні саліт - феросаліт), анортит - альбіт (проміжні лабрадор - андезин - олігоклаз) більш магнезіальні кінцеві члени названих та інших ізоморфних серій фемічних мінералів і плагіоклази з вищим вмістом анортитової молекули вважають більш високотемпературними. Це найчастіше спостерігається в магматичних базальтоїдних серіях порід, в яких кінцеві диференціати характеризуються більш залізистими мінералами, а фельдшпатоїдно-польовошпатові серії завершуються евтектоїдними фонолітовими або гранітоїдними диференціатами.

() С.Г. КРИВДІК, 2019

Проте цей принцип не завжди витримується. У процесі кристалізації природних магм (та й розчинів) спрацьовують такі фактори як фугітивність кисню, зміна тиску, як це розглянуто в одній з публікацій [4]. Так, Родер і Емслі [15] показали, що склад олівіну та мінералів групи шпінелі в базальтових розплавах залежать не стільки від температури кристалізації, а більше від фугітивності кисню. Петрологам [14] давно відома роль магнетиту в розплавах, кристалізація якого може привести до підвищення магнезіальності фемічних мінералів.

У цьому повідомленні автор намагається частково висвітлити деякі з зазначених вище дещо нестандартних ефектів кристалізації розплавів на прикладі парагенезисів Чернігівського карбонатитового масиву (Західне Приазов'я).

ISSN 2519-2396. Mineral. Journ. (Ukraine). 2019. 41, No 3 
Мета роботи та методи досліджень. Мінеральні парагенезиси карбонатитів Чернігівського масиву виявилися досить специфічними і схоже на те, що вони є унікальними і неповторними серед карбонатитів інших відомих комплексів. Тому автор намагався дати петрогенетичну інтерпретацію цього явища з доповненням деякими новими ідеями, припущеннями, міркуваннями стосовно раніше опублікованих поглядів [2, 8] щодо генезису цих карбонатитів. Після виходу вказаних публікацій було виконано ізотопно-геохімічні дослідження (ізотопного складу O, C, Sr) [9], результати яких ще переконливіше засвідчили раніше розроблені петрогенетичні концепції й дали поштовх для міркувань стосовно деяких незрозумілих моментів механізму кристалізації карбонатитів. Для пояснення цих ізотопногеохімічних результатів довелося узгоджувати ix із такими параметрами як залізистість мінералів та залежність їх від ступеня окисненості заліза (кількості магнетиту в породах), а також залучити реакції дисоціації карбонатитового розплаву (передусім молекули $\mathrm{FeCO}_{3}$ ).
Така петрогенетична інтерпретація базувалася переважно на результатах хімічних аналізів порід і мінералів, визначенні ізотопного складу О і С у карбонатах карбонатитів, а також розрахунках температури та тиску формування цих порід на відомих мінеральних та ізотопно-геохімічних геотермометрах і геобарометрах. Попередньо детально досліджено геологічне положення карбонатитів (у межах лінійно витягнутого комплексу), виконано петрографічне дослідження шліфів, петрохімічні розрахунки результатів хімічного аналізів порід тощо.

Виклад результатів досліджень. Серед карбонатитів Чернігівського масиву, мінеральний склад яких розглянуто в аспекті поставленої мети, виявилися найбільш показовими альвікіти - кальцитові карбонатити з апатитом, олівіном, клінопіроксеном, флогопітом, амфіболом, магнетитом та ільменітом. У різних дайкоподібних тілах цих карбонатитів хімічний склад названих мінералів є досить варіабельним (олівін - від $\mathrm{Fa}_{17}$ до $\mathrm{Fa}_{65}$ ) передусім за рівнем магнезіальності (табл. 1, 2), при цьому

Таблиця 1. Хімічний склад деяких олівінвмісних карбонатитів (альвікітів та бефорситів) Чернігівського масиву, \% Table 1. The chemical composition of some olivine-containing carbonatites (alvikites and beforsites) of the Chernihivka massif, \%

\begin{tabular}{|c|c|c|c|c|c|c|c|c|c|c|c|}
\hline \multirow{2}{*}{$\begin{array}{c}\text { Компонент, } \\
\text { коефіцієнт }\end{array}$} & \multicolumn{5}{|c|}{ Номер зразка } & \multirow{2}{*}{$\begin{array}{l}\text { Компонент, } \\
\text { коефіцієнт }\end{array}$} & \multicolumn{5}{|c|}{ Номер зразка } \\
\hline & $1003 / 969$ & $797 / 299$ & $1058 / 270$ & $865 / 971$ & $132 / 290$ & & $1003 / 969$ & $797 / 299$ & $1058 / 270$ & $865 / 971$ & $132 / 290$ \\
\hline $\mathrm{SiO}_{2}$ & 4,98 & 4,70 & 6,58 & 5,08 & 2,89 & $\mathrm{~K}_{2} \mathrm{O}$ & 0,29 & 0,14 & 0,52 & 0,19 & 0,29 \\
\hline $\mathrm{TiO}_{2}$ & 0,35 & 0,37 & 0,51 & 0,31 & 0,07 & $\mathrm{P}_{2} \mathrm{O}_{5}$ & 5,90 & 4,32 & 4,90 & 4,61 & 3,31 \\
\hline $\mathrm{Al}_{2} \mathrm{O}_{3}$ & 0,41 & 0,27 & 0,55 & 0,13 & 0,57 & $\mathrm{~S}$ & 0,31 & 0,25 & 0,25 & 0,24 & Сл. \\
\hline $\mathrm{TR}_{2} \mathrm{O}_{3}$ & - & - & - & - & 0,61 & $\mathrm{H}_{2} \mathrm{O}^{-}$ & 0,07 & 0,10 & 0,15 & 0,17 & 0,19 \\
\hline $\mathrm{Fe}_{2} \mathrm{O}_{3}$ & 4,00 & 3,85 & 3,05 & 2,09 & 3,53 & В. п. п. & 1,10 & 1,53 & 1,43 & 2,66 & 0,74 \\
\hline $\mathrm{FeO}$ & 2,88 & 3,31 & 4,03 & 5,90 & 6,48 & $\mathrm{CO}_{2}$ & 29,38 & 30,09 & 28,32 & 29,02 & 35,40 \\
\hline $\mathrm{MnO}$ & 0,25 & 0,19 & 0,25 & 0,34 & 0,89 & $\mathrm{C}_{\mathrm{opr}}$ & - & - & - & 0,06 & 0,19 \\
\hline $\mathrm{MgO}$ & 4,07 & 4,58 & 4,70 & 3,09 & 13,85 & $\mathrm{~F}$ & 0,06 & - & 0,10 & 0,16 & 0,04 \\
\hline $\mathrm{CaO}$ & 45,83 & 44,32 & 43,18 & 45,83 & 29,77 & $\Sigma$ & 100,21 & 100,64 & 100,12 & 100,24 & 100,26 \\
\hline $\mathrm{SrO}$ & $(\geq 1)^{*}$ & 2,36 & 1,20 & $(\geq 1)$ & 1,20 & $\begin{array}{l}(\mathrm{Fe}+\mathrm{Mn}) / \\
(\mathrm{Fe}+\mathrm{Mn}+\mathrm{Mg})\end{array}$ & 0,48 & 0,46 & 0,46 & 0,60 & 0,30 \\
\hline $\mathrm{BaO}$ & $(0,02)^{*}$ & $(0,02)$ & $(0,02)$ & $(0,02)$ & $(0,1)$ & $\mathrm{Fe}^{3+} / \mathrm{Fe}_{\text {заг }}$ & 0,56 & 0,51 & 0,40 & 0,24 & 0,39 \\
\hline $\mathrm{Na}_{2} \mathrm{O}$ & 0,33 & 0,26 & 0,40 & 0,36 & 0,24 & & & & & & \\
\hline
\end{tabular}

П р и м і т к а. * - у дужках наведено результати спектрального аналізу, які в суму не включено; зразки 1003/969, 797/299, 1058/270 - альвікіти з магнезіальними парагенезисами (слюда представлена тетраферифлогопітом; аналізи розташовані за порядком зростання залізистості мінералів (аналізи олівінів див. табл. 2); зр. 865/971 - альвікіт з найбільш залізистим парагенезисом; зр. 132/900 - доломітовий (анкеритовий) бефорсит із найбільш залізистим (з проаналізованих) олівіном. Сл. - сліди (тут і у табл. 2).

N o t e. ${ }^{*}$ - results of the spectral analysis, which are not included in to the sum; sample 1003/969, 797/299, 1058/270 alvikites with magnesian parageneses (mica is represented by tetraferriphlogopite, analytical data are ordered by iron rise in minerals (data on olivine are shown in Table 2), smp. 865/971 - alvikite with the most iron parageneses; smp. 132/290 dolomite (ankerite) beforsite with olivine mostly enriched in Fe (among analyzed). Сл. — traces (here and in Table 2). 


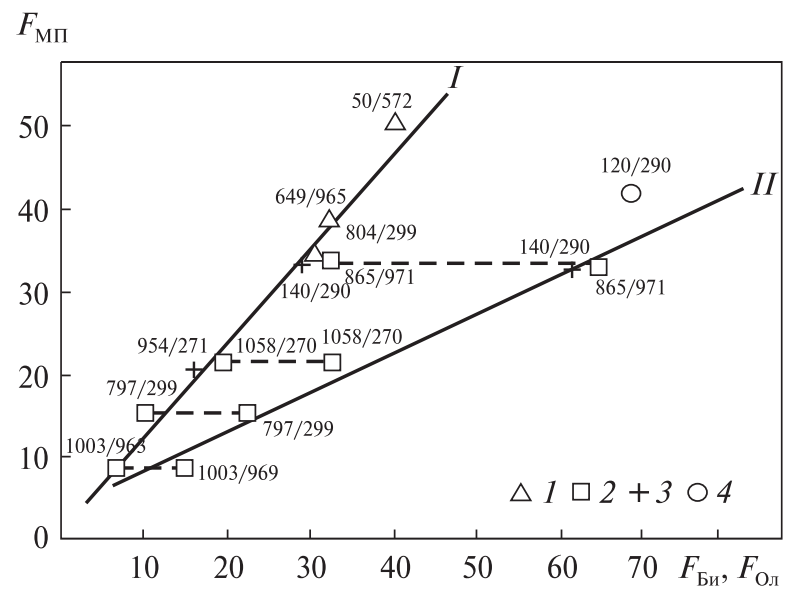

Кореляційна залежність залізистості співіснуючих клінопіроксенів і біотитів (I), клінопіроксенів і олівінів (II). Породи: 1 - сьовіти, 2 - альвікіти, 3 - слюдяні перидотити, 4- мельтейгіти

Correlation dependence of $\mathrm{Fe} /(\mathrm{Fe}+\mathrm{Mg})$ in the coexisting clinopyroxenes and biotites (I), clinopyroxenes and olivines (II). Rocks: 1 - sovites, 2 - alvikites, 3 - mica peridotites, $4-$ melteigites

Таблиия 2. Хімічний склад олівінів із альвікітів та залізистого бефорситу Чернігівського масиву, \% Table 2. Chemical composition of olivines from alvikites and enriched in iron beforcite of Chernihivka massif, \%

\begin{tabular}{|l|r|r|r|c|}
\hline \multirow{2}{*}{\multicolumn{1}{|c|}{ Компонент, }} & \multicolumn{4}{|c|}{ Комер зразка } \\
\cline { 2 - 5 } & $797 / 299$ & $1058 / 270$ & $865 / 971$ & $132 / 290$ \\
\hline $\mathrm{SiO}_{2}$ & 38,17 & 37,32 & 33,25 & - \\
$\mathrm{TiO}_{2}$ & 0,10 & 0,05 & 0,12 & - \\
$\mathrm{Al}_{2} \mathrm{O}_{3}$ & 0,11 & 0,18 & 0,22 & - \\
$\mathrm{Fe}_{2} \mathrm{O}_{3}$ & 0,98 & 1,41 & 1,60 & $47,50 *$ \\
$\mathrm{FeO}^{2}$ & 19,30 & 25,40 & 48,10 & - \\
$\mathrm{MnO}$ & 0,76 & 1,48 & 1,18 & 1,63 \\
$\mathrm{MgO}$ & 40,42 & 34,10 & 15,16 & 19,00 \\
$\mathrm{CaO}$ & 0,14 & 0,14 & 0,21 & 0,20 \\
$\mathrm{Na}_{2} \mathrm{O}$ & 0,03 & 0,24 & 0,20 & - \\
$\mathrm{K}_{2} \mathrm{O}$ & $\mathrm{Cл.}$ & Сл. & 0,04 & - \\
$\mathrm{P}_{2} \mathrm{O}_{5}$ & 0,09 & 0,02 & - & - \\
$\mathrm{H}_{2} \mathrm{O}^{-}$ & 0,02 & 0,00 & 0,16 & - \\
$\mathrm{B.} \mathrm{П.} \mathrm{П.}$ & 0,33 & 0,07 & 0,24 & - \\
$\Sigma$ & 100,45 & 100,41 & 100,48 & - \\
$(\mathrm{Fe}+\mathrm{Mn}) /(\mathrm{Fe}+$ & 0,23 & 0,32 & 0,65 & 0,57 \\
$+\mathrm{Mn}+\mathrm{Mg})$ & & & & \\
\hline
\end{tabular}

Примітка. Номери зразків ті ж, що і в табл. 1. У зр. 1003/969 олівін не аналізували, а за показниками заломлення поодиноких зерен його склад варіює від $\mathrm{Fa}_{15}$ до $\mathrm{Fa}_{17}$ (див. рисунок); ${ }^{*}-\mathrm{Fe}_{2} \mathrm{O}_{3 \text { tot }}$.

Note. Sample numbers are the same as in Table 1. Olivine of smp. 1003/969 is not analyzed. But based on optical peculiarities, its composition varies from $\mathrm{Fa}_{15}$ to $\mathrm{Fa}_{17}$ (see Figure); ${ }^{*}-\mathrm{Fe}_{2} \mathrm{O}_{3 \text { tot }}$. переважає взаємопов'язана залежність (позитивна кореляція) хімізму співіснуючих мінералів (рисунок). У найбільш залізистих парагенезисах карбонатитів олівін складу $\mathrm{Fa}_{65}$ асоціює 3 акмітвмісним салітом, залізистим флогопітом, амфіболом підвищеної залізистості, ільменітом, тоді як у магнезіальних парагенезисах магнезіальний олівін $\left(\mathrm{Fa}_{23}\right)$ - iз діопсидом, магнезіальним флогопітом (тетраферифлогопітом), пікроільменітом (5,3-6,1% MgO), що й ілюструє рисунок. Паралельно з цим відбувається направлена зміна хімізму кальциту - в альвікітах із залізистим парагенезисом він містить 1,44 \% FeO, а у магнезіальному з менш залізистими силікатами - 0,57 \%. Ще вищий вміст $\mathrm{FeO}(2,30 \%)$ фіксується в кальцитах деяких зразків сьовітів. Окрім того, в альвікіті з залізистим парагенезисом мінералів значно менша відносна кількість магнетиту і відповідно нижча окисненість заліза в породі (табл. 1). Більше того, в залізистому парагенезисі магнетит виявився більш "високотемпературним" i, за даними хімічного аналізу, містить 6,2\% $\mathrm{TiO}_{2}$, тоді як в магнезіальному - лише $1,52 \% \mathrm{TiO}_{2}$. Тобто схоже на те, що мінерали більш залізистих парагенезисів у альвікітах кристалізувалися за умов вищої температури (принаймні за нижчої фугітивності кисню - в них менш окиснене залізо). Це частково підтверджується розрахунками температури за олівін-клінопіроксеновим геотермометром [6, 7].

Цікаво, що ці не зовсім зрозумілі, на перший погляд, особливості виявлених залежностей, проявляються навіть на ізотопному рівні. У попередніх публікаціях показано, що в "залізистому" альвікіті ізотопний склад кисню та вуглецю $\left(\delta^{18} \mathrm{O}=+6,1 \%\right.$, $\delta^{13} \mathrm{C}=-5,1 \%$ ) є типово карбонатитовим ("глибинним"), а в альвікітах з магнезіальним парагенезисом значно зростає частка "важкого" кисню $\left(\delta^{18} \mathrm{O}=+8 \%\right.$, а $\delta^{13} \mathrm{C}=-9,5 \%$ ) [9]. Розрахунок температури за цими ізотопними характеристиками теж показує, що мінерали із карбонатиту, що має більш залізистий парагенезис мінералів, є більш високотемпературними - 1050 і $971{ }^{\circ} \mathrm{C}$ відповідно (про магнетит йшлося вище), ніж магнезіального. Близьку до цих значень температуру (966-1000 ${ }^{\circ} \mathrm{C}$ ) розраховано і за олівін-клінопіроксеновим геотермометром [7].

До цього можна ще навести такий, на погляд автора, феноменальний приклад, як наявність високозалізистих (до $\mathrm{Fa}_{57}$ ) олівінів у доломітових карбонатитах Чернігівського масиву. Більше ISSN 2519-2396. Mineral. Journ. (Ukraine). 2019. 41, No 3 
того, в доломіті із бефорситу з таким високозалізистим олівіном зафіксовано 5,76 \% FeO. У цій же породі наявний доломіт зі ще вищим вмістом заліза і дещо більш залізистий олівін. Методом "мокрої" хімії вдалося проаналізува-

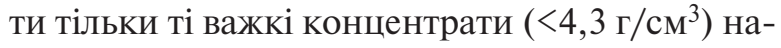
званих мінералів, наважок яких було достатньо для хімічного аналізу. Отже, залишилися не проаналізованими важкі концентрати мінера-

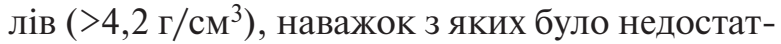
ньо для хімічного аналізування, і тих, що були "засмічені" важкими рудними мінералами (зокрема ніобатами). Карбонати (доломіт) із таким вмістом заліза в літературі також називають анкеритами [3, 13]. За уявленнями більшості дослідників карбонатитів, відомості яких узагальнені В.С. Самойловим [12], анкеритові (та й доломітові) карбонатити вважають низькотемпературними (доломітизованими) утвореннями, чого не можна аж ніяк сказати про бефорсити Чернігівського масиву з олівіном та численними структурами розпаду твердих розчинів карбонатів (ексолюційні вростки доломіту в кальциті і навпаки; останнє трапляється рідко і було виявлено, можливо вперше, B.I. Воробйовим, фото цих структур було передано авторові.

Хоча в бефорситах (у різних тілах) виявлено такі ж широкі межі інтервалу коливань хімізму олівінів (хризоліт - гортоноліт) та флогопітів, проте все ще не вдалося з такою детальністю дослідити їхні залежності та ізотопний склад кисню та вуглецю, як це зроблено для альвікітів.

Обговорення результатів досліджень. Петрогенетична інтерпретація, висновки. Для пояснення коротко розглянутої корелятивної залежності хімізму фемічних мінералів від ступеня окисненості заліза в карбонатитах автор висловлює припущення про термічну дисоціацію сидеритової молекули $\left(\mathrm{FeCO}_{3}\right)$ в карбонатитовому розплаві за схемою $3 \mathrm{FeCO}_{3}=\mathrm{Fe}_{3} \mathrm{O}_{4}+$ $+\mathrm{CO}+2 \mathrm{CO}_{2}$ та/або $6 \mathrm{FeCO}_{3}=2 \mathrm{Fe}_{3} \mathrm{O}_{4}+$ $+5 \mathrm{CO}_{2}+\mathrm{C}_{(\text {графіт) }}$. За останньою реакцією можна частково пояснити наявність графіту в карбонатитах та інших породах Чернігівського масиву.

До цього можна додати, що термічна дисоціація $\mathrm{FeCO}_{3}$ відбувалася у тих випадках (i окремих тілах карбонатитів), коли карбонатитовий розплав заповнював порожнини (тріщини), де суттєвіше понижувався тиск, що сприяло цій дисоціації із кристалізацією та осадженням магнетиту і зумовлювало зниження вмісту за- ліза в розплаві й утворення магнезіальних силікатів та карбонатів зі зниженим вмістом FeO. У тих же карбонатитових розплавах, які не зазнавали різкого пониження тиску, сидеритова молекула утримувалася до кінця кристалізації. При цьому залізо у двовалентному стані входило переважно до складу силікатів (олівінів, піроксенів, слюд та карбонатів), а незначна його частка - до магнетиту.

Можна також припустити, що зниження тиску у тріщинах, які заповнював розплав, зумовило ефект деякого зниження температури (як у розріджених газах і фріонах у холодильних камерах), що фіксується і в хімізмі магнетиту, та зміщення ізотопного складу кисню в область нижчої температури. Ймовірно, суттєвого зниження температури не відбувалося, але окисненість заліза в результа-ті термічної дисоціації молекули $\mathrm{FeCO}_{3}$ зумовила ізотопне зміщення кисню (через перерозподіл між $\mathrm{CO}_{2}$ i $\mathrm{CO}$ ), а кристалізація магнетиту i його відсадка сприяли підвищенню відносної кількості $\mathrm{MgO}$ в розплаві та виділення більш магнезіальних силікатів. Тобто підвищена магнезіальність фемічних мінералів (передусім олівіну) в альвікітах з магнезіальними парагенезисами (і магнетитом) аж ніяк не зумовлена вищою температурою кристалізації порівняно 3 карбонатитами із більш залізистими ("низькотемпературними") парагенезисами.

Як було нами показано раніше [9], в лінійно витягнутому Чернігівському карбонатитовому масиві проявляється збільшення величини $\delta^{18} \mathrm{O}$ (аж до $17 \%$ ) у напрямку 3 півночі на південь. У цьому ж напрямку відбувається пониження магнезіальності силікатів у карбонатитах, підвищується ступінь окисненості заліза з виділенням магнетиту. Саме в цьому напрямку, на нашу думку, зменшується глибина ерозійного зрізу.

Значні коливання ізотопного складу кисню, меншою мірою вуглецю, в карбонатах карбонатитів різних комплексів наведено В.М. Кулешовим [11], він вказує різні причини таких коливань, проте запропонований автором механізм дисоціації сидеритового компонента не розглядає. Окрім того, таких "аномальних" високозалізистих парагенезисів фемічних мінералів у карбонатитах, як це характерно для Чернігівського масиву, до теперішнього часу не описано [5].

Наприкінці ще раз зауважимо, що, як зазначено у попередніх публікаціях автора [2, 8], Чер- 
нігівський масив з такими залізистими олівінами $\left(\mathrm{Fa}_{70}\right)$ в карбонатитах і лужних породах $\epsilon$, очевидно, поки що єдиним серед інших карбонатитових комплексів світу. $Е$ підстави вважати, що ці та інші особливості петрології, мінералогії та геохімії, розглянуті в попередніх пуб- лікаціях, зумовлені абісальними умовами та можливими вказаними варіаціями тиску в процесі формування цього масиву. Це один з найглибше (до 20 км) [2, 10] еродованих карбонатитових комплексів (за геотермометром А.С. Таланцева [13], розраховано тиск у межах 3-6 кбар).

\section{ЛІТЕРАТУРА}

1. Воробьев Е.И. Полифазный тип распада апатита. Геохимия. 2000. № 5. С. 661-664.

2. Глевасский Е.Б., Кривдик С.Г. Докембрийский карбонатитовый комплекс Приазовья. Киев: Наук. думка, 1981. 228 c.

3. Дир У.А., Хауи Р.А., Зусман Дж. Породообразующие минералы. М.: Мир, 1966. Т. 5. 408 с.

4. Дубина О.В., Кривдік С.Г. Ефект Соре в петрології магматичних порід. Мінерал. журн. 2010. 32, № 4. С. 51 - 62.

5. Карбонатиты / Ред. О. Таттл, Дж. Гиттинс. М.: Мир, 1969. 468 с.

6. Кривдик С.Г. Оливины Черниговского карбонатитового комплекса (Западное Приазовье). Минералогические критерии поисков редких и цветных металлов в пределах Украинского щита. Киев: Наук. думка, 1977. С. 61-75.

7. Кривдик С.Г. Условия образования карбонатитов черниговского комплекса (Западное Приазовье) по данным минералогических геотермометров. Минералогические критерии поисков редких и цветных металлов в пределах Украинского щита. Киев: Наук. думка, 1977. С. 75-81.

8. Кривдик С.Г., Ткачук В.И. Петрология щелочных пород Украинского щита. Киев: Наук. думка, 1990. 408 с.

9. Кривдик С.Г., Загнитко В.Н., Луговая И.П. Изотопный состав минералов в карбонатитах Черниговского массива (Приазовье) как индикатор условий их кристаллизации. Минерал. журн. 1997. 19, № 6. С. $28-42$.

10. Кривдік С.Г., Дубина О.В. Типохімізм мінералів лужно-ультраосновних порід Українського щита як індикатор глибинності їх формування. Мінерал. журн. 2005. 27, № 1. С. 64-76.

11. Кулешов В.Н. Изотопный состав и происхождение глубинных карбонатитов. М.: Наука, 1986. 125 с.

12. Самойлов В.С. Карбонатиты (фации и условия образования). М.: Наука, 1977. 292 с.

13. Таланцев А.С. Доломит-кальцитовый геологический термометр. Докл. АН СССР. 1976. 228, № 3. С. $701-704$.

14. Эволюция изверженных пород / Под ред. Х. Йодер. М.: Мир, 1983. 522 с.

15. Roeder F.L., Emslie D.F. Olivine-liquid Equilibrium. Contribs. Mineral. and Petrol. 1970. 29, № 4. P. $275-289$.

Надійшла 31.05.2019

\section{REFERENCES}

1. Vorobjev, E.I. (2000), Geochemistry, No. 5, Moscow, RU, pp. 661-664 [in Russian].

2. Hlevasskyy, E.B. and Kryvdik, S.G. (1981), Precamrian carbonatitic complex of Azov area, Nauk. dumka, Kyiv, UA, 228 p. [in Russian].

3. Deer, W.A., Howie, R.A. and Zussman, J. (1966), Rock-forming minerals, Vol. 5, Mir press, Moscow, RU, 408 p. [in Russian].

4. Dubyna, O.V. and Kryvdik, S.G. (2016), Mineral. Journ. (Ukraine), Vol. 32, No. 4, Kyiv, UA, pp. $51-62$ [in Ukrainian].

5. Tattl, O.F. and Hittins, J. (eds) (1969), Carbonatites, Mir press, Moscow, RU, 468 p. [in Russian].

6. Kryvdik, S.G. (1977), Mineralohicheskie kriterii poiskov redkih i tsvetnyh metallov v predelah Ukrainskoho shchita, Nauk. dumka, Kyiv, UA, pp. 61-75 [in Russian].

7. Kryvdik, S.G. (1977), Mineralohicheskie kriterii poiskov redkih i tsvetnyh metallov v predelah Ukrainskoho shchita, Nauk. dumka, Kyiv, UA, pp. 75-81 [in Russian].

8. Kryvdik, S.G. and Tkachuk, V.I. (1990), Petrology of alkaline rocks of the Ukrainian Shield, Nauk. dumka, Kyiv, UA, 408 p. [in Russian].

9. Kryvdik, S.G., Zagnitko, V.M. and Luhovaya, I.P. (1997), Mineral. Journ. (Ukraine), Vol. 19, No. 6, Kyiv, UA, pp. 28-42 [in Russian].

10. Kryvdik, S.G. and Dubyna, O.V. (2005), Mineral. Journ. (Ukraine), Vol. 27, No. 1, Kyiv, UA, pp. $64-76$ [in Ukrainian].

11. Kuleshov, V.N. (1986), Isotope composition and genesis of deep-derived carbonatites, Nauka, Moscow, RU, 125 p. [in Russian].

12. Samojlov, V.S. (1977), Carbonatites (facies and condition), Nauka, Moscow, RU, 292 p. [in Russian].

13. Talantsev, A.S. (1976), Dokl. AN SSSR, Vol. 228, No. 3, Moscow, RU, pp. 701-704 [in Russian].

14. Yoder, H.S. (ed) (1983), The evolution of the igneous rocks, Mir, Moscow, RU, 522 p. [in Russian].

15. Roeder, F.L. and Emslie, D.F. (1970), Contribs. Mineral. and Petrol., Vol. 29, No. 4, pp. 275-289.

Received 31.05.2019 


\section{С.Г. Кривдик}

Институт геохимии, минералогии и рудообразования

им. Н.П. Семененко НАН Украины

03142, г. Киев, Украина, пр-т Акад. Палладина, 34

E-mail: kryvdik@ukr.net

\section{СПЕЦИФИКА ПАРАГЕНЕЗИСОВ МИНЕРАЛОВ В КАРБОНАТИТАХ ЧЕРНИГОВСКОГО МАССИВА (ЗАПАДНОЕ ПРИАЗОВЬЕ)}

Карбонатиты черниговского комплекса резко отличаются от подобных карбонатитов других комплексов рядом минералогических, петрологических и геохимических особенностей. Наиболее впечатляет необычно высокая железистость оливинов (в карбонатитах до $\mathrm{Fa}_{65}$, в ийолит-мельтейгитах $-\mathrm{Fa}_{70}$ ). В карбонатитах и щелочных породах выявлен широкий интервал вариаций химизма - от $\mathrm{Fa}_{10-15}$ до $\mathrm{Fa}_{70}$. При этом проявляется зависимость между железистостью оливина (и других фемических минералов) и окисленностью железа (кристаллизацией магнетита). С увеличением количества последнего возрастает магнезиальность оливина. Железистые оливины ассоциируют с обогащенными железом кальцитом $(1,4 \% \mathrm{FeO})$ и доломитом $(>5,8 \% \mathrm{FeO})$. Одним из факторов такой зависимости можно считать термическую диссоциацию сидеритовой молекулы $\left(\mathrm{FeCO}_{3}\right)$ карбонатитового расплава с образованием $\mathrm{Fe}_{3} \mathrm{O}_{4}$ (магнетита), $\mathrm{CO}, \mathrm{CO}_{2}$ и $\mathrm{C}$ (графита). Из-за отсадки магнетита расплав обогащается $\mathrm{MgO}$ и кристаллизуются более магнезиальные оливины (и другие минералы). Это подтверждают также результатами изотопно-геохимических исследований: в кальцитах железистых парагенезисов $\delta^{18} \mathrm{O}$ и $\delta^{13} \mathrm{C}$ имеют типичные для карбонатитов значения $(+6,1$ и $-5,1 \%$ соответственно), тогда как в магнезиальных (с магнетитом) проявляется отклонение от "глубинных" значений $\left(\delta^{18} \mathrm{O}\right.$ становится +8 и до $+17,5 \%$, а $\delta^{13} \mathrm{C}--9,5 \%$ ). Полученные по изотопным данным значения температуры составляют для железистых парагенезисов $1050{ }^{\circ} \mathrm{C}$, а для магнезиальных $-971^{\circ} \mathrm{C}$. Такие особенности карбонатитов черниговского комплекса обусловлены абиссальными условиями их формирования. Этот комплекс является одним из наиболее глубоко эродированных (до 20 км).

Ключевые слова: карбонатиты с высокожелезистым оливином (до $\mathrm{Fa}_{65}$ ), глубокий эрозионный срез, диссоциация молекулы $\mathrm{FeCO}_{3}$.

\section{S.G. Kryvdik}

M.P. Semenenko Institute of Geochemistry, Mineralogy

and Ore Formation of the NAS of Ukraine

34, Acad. Palladin Ave., Kyiv, Ukraine, 03142

E-mail: kryvdik@ukr.net

\section{SPECIFICITY OF MINERAL PARAGENESISES IN CARBONATITES OF CHERNIHIVKA MASSIF (WESTERN AZOV AREA)}

The carbonatites of the Chernihivka complex sharply differ from the similar carbonatites of other complexes by a number of mineralogical, petrological and geochemical features. Among the most spectacular is an unusually high iron content in olivines (up to $\mathrm{Fa}_{65}$ in carbonatites and $\mathrm{Fa}_{70}$ in ijolite-melteigites). Carbonatites and alkaline rocks show wide range variations in chemical composition of olivine, from $\mathrm{Fa}_{10-15}$ to $\mathrm{Fa}_{70}$. At the same time, the dependence between the iron index in olivine (and other femic minerals) and the oxidation of iron (crystallization of magnetite) is observed. Mg\# index of olivine rises at more magnetite present. High-Fe olivines are associated with iron-rich calcite $(1.4 \% \mathrm{FeO})$ and dolomite $(>5.8 \%$ $\mathrm{FeO})$. As one reason of this dependence is considered to be the thermal dissociation of siderite $\left(\mathrm{FeCO}_{3}\right)$ of carbonatite melt that is accompanied by formation of magnetite, $\mathrm{CO}, \mathrm{CO}_{2}$ and $\mathrm{C}$ (graphite). As a result of magnetite grains sinking, the residual melt becomes enriched in $\mathrm{MgO}$ and magnesian olivines (and other minerals) crystallized. This fact is also proved by the results of isotope-geochemical studies. Calcites of enriched in iron association show $\delta^{18} \mathrm{O}$ and $\delta^{13} \mathrm{C}$ values typical of carbonatites $(+6.1$ and $-5.1 \%$, respectively), whereas in magnesia varieties (with magnetite) indicate deviation from "mantle" range $\left(\delta^{18} \mathrm{O}\right.$ from +8 up to $+17.5 \% o, \delta^{13} \mathrm{C}$ to $-9.5 \% o$ ). The temperatures determined on isotopic data range from $1050{ }^{\circ} \mathrm{C}$ for enriched in iron to $971^{\circ} \mathrm{C}$ for magnesian paragenesises. Such features of carbonatites of the Chernihivka complex are supposed to indicate abyssal conditions of their crystallization, with this complex being one of the most deeply eroded (up to $20 \mathrm{~km}$ ).

Keywords: carbonatites with high-iron olivine (up to $\mathrm{Fa}_{65}$ ), deep erosion level, dissociation of the $\mathrm{FeCO}_{3}$ molecule. 